\title{
EFEKTIVITAS PROGRAM PEMBINAAN KESADARAN BERBANGSA DAN BERNEGARA TERHADAP NARAPIDANA KHUSUS KORUPSI DI LEMBAGA PEMASYARAKATAN KELAS IIA AMBON
}

\author{
Nasaruddin Umar ${ }^{1}$, Fahri Bachmid ${ }^{2 *}$ \\ ${ }^{1}$ Dosen Fakultas Syariah dan Ekonomi Islam, Institut Agama Islam Negeri Ambon \\ ${ }^{2}$ Dosen Fakultas Hukum, Universitas Muslim Indonesia, Makassar \\ *Penulis Korespondensi: Fahri Bachmid \\ Email Korespondensi: fahri.bachmid@umi.ac.id
}

\begin{abstract}
Abstrak. Penelitian ini bertujuan untuk mengetahui dan menganalisis efektivitas program pembinaan kesadaran berbangsa dan bernegara terhadap narapidana khusus korupsi di Lembaga Pemasyarakatan Kelas IIA Ambon, serta faktor-faktor yang mempengaruhinya. Tipe penelitian yang digunakan adalah penelitian hukum empiris yang bersifat deskriptif kualitatif. Penelitian ini dilakukan di Lembaga Pemasyarakatan Kelas IIA Ambon. Teknik pengumpulan data yang digunakan dalam penelitian ini adalah wawancara, dokumentasi, dan studi pustaka. Adapun teknik analisis data yang digunakan adalah teknik analisis data kualitatif. Hasil penelitian menunjukkan bahwa program pembinaan kesadaran berbangsa dan bernegara terhadap narapidana khusus korupsi di Lembaga Pemasyarakatan Kelas IIA Ambon belum berjalan secara efektif. Hal ini disebabkan masih adanya sejumlah kendala, yakni adanya keterbatasan program pembinaan dari pemerintah pusat, kewenangan yang dimiliki, kurangnya anggaran, minimnya sarana dan prasarana serta kurangnya SDM dalam menunjang kepribadian berbangsa bernegara, sebab kegiatan pembinaannya masih sebatas kegiatan upacara bendera. Adapun Faktor yang mempengaruhi efektivitas pembinaan yakni ketersediaan regulasi yang kurang mendukung, ketersediaan sumber daya manusia yang belum memadai dan ketersediaan anggara pembinaan yang masih kecil. Selanjutnya, disarankan agar dilakukan penambahan tenaga Sumber Daya Manusia yang memiliki kapasitas dan kompetensi untuk memberikan bekal yang cukup bagi narapidana khusus korupsi. Lebih lanjut, diperlukan perubahan regulasi di bidang lembaga kemasyarakatan dengan memberikan kewenangan kepada pihak Lembaga Pemasyarakatan untuk dapat melakukan berbagai Nota Kesepahaman dengan berbagai instansi guna mengoptimalkan kerjasama kegiatan pembinaan di bidang kesadaran berbangsa dan bernegara.
\end{abstract}

Kata Kunci:

Efektivitas;

Lembaga Pemasyarakatan; Narapidana Khusus Korupsi; Pembinaan. 


\section{PENDAHULUAN}

Masalah kesadaran hukum dalam kehidupan berbangsa dan bernegara dewasa ini merupakan satu terma yang sedang mendapat perhatian dan sorotan publik (Siti Merida Hutagalung, 2011). Betapa tidak, integritas dan komitmen kebangsaan seakan luntur akibat semakin menurunnya semangat kebangsaan dan lemahnya tingkat kesadaran hukum warga negara (Ibrahim Ahmad, 2018). Hal ini dibuktikan dengan maraknya kasus-kasus pelanggaran hukum dan main hakim sendiri (eigenrichting) yang terjadi di Indonesia (Chandro Panjaitan \& Firman Wijaya, 2018).

Munculnya berbagai tindak pidana yang cukup menyita perhatian publik seperti kasuskasus intoleransi bermuatan SARA seperti di Papua (Ainna Amalia \& Ricardo Freedom Nanuru, 2018), intimidasi dan dugaan kriminalisasi ulama (Salman Al Farisi, 2018), demo anarkis di berbagai daerah (Dimas Prasetyo, 2017), hingga maraknya kasus korupsi yang terus melanda bangsa ini (La Ode Husen, 2015), baik yang melibatkan pejabat di daerah maupun pejabat negara seperti kasus tindak pidana korupsi yang menjerat tersangka mantan Menteri Sosial RI Idrus Marham dalam dugaan kasus suap PLTU (M. Rosseno Aji, 2019), penetapan tersangka Imam Nahrawi Menteri Pemuda dan Olah Raga tentang dugaan suap dana bantuan hibah Kemenpora (Ibnu Hariyanto, 2019), kasus suap dalam proses seleksi jabatan di Kementerian Agama (Miftah Salis, 2019), korupsi berjamaah 41 anggota DPRD Kota Malang dalam kasus suap APBD Tahun 2015 Kota Malang (Haris Fadhil, 2018), dan yang paling menyedihkan adalah terjeratnya kembali Bupati Kudus dalam tindak pidana korupsi untuk yang kedua kalinya (Ilham Rian Pratama, 2019), menunjukkan persoalan korupsi di Indonesia kian massif dan meluas.

Fenomena ini menunjukkan telah terjadi krisis kesadaran berbangsa bernegara khususnya kesadaran dan ketaatan hukum secara nasional. Kondisi tersebut juga merambak di berbagai daerah dengan banyaknya kasus operasi tangkap tangan (OTT) oleh KPK tidak terkecuali di Kota Ambon (Choirul Arifin, 2018). Maraknya kasuskasus korupsi baik yang sedang ditangani pihak kepolisian maupun yang telah vonis dan berkekuatan hukum tetap menempati urutan ketiga tindak pidana terbesar di Kota Ambon.

Berdasarkan data dari Lembaga Pemasyarakatan (Lapas) Kelas IIA Ambon, untuk tahun 2018 saja paling tidak warga binaan untuk kasus tindak pidana korupsi mencapai 51 orang merupakan tindak pidana tertinggi ketiga dari 21 jenis kejahatan yang dilakukan oleh narapidana di Lapas Kelas IIA Ambon. Jenis kejahatan yang tertinggi adalah pidana narkoba sebanyak 111 orang, menyusul pidana perlindungan anak 109 orang dan beberapa kasus pidana khusus seperti kesusilaan 26 orang dan kasus makar RMS berjumlah 8 orang, sebagaimana dapat dilihat pada tabel di bawah ini:

Tabel 1. Tingkat Tindakan Pidana Khusus di Lapas Kelas IIA Ambon

\begin{tabular}{c|l|c}
\hline \hline No. & \multicolumn{1}{|c|}{ Jenis Kejahatan Khusus } & Jumlah \\
\hline \hline 1 & Pidana Narkoba & 111 Orang \\
\hline 2 & Pidana Perlindungan Anak & 109 Orang \\
\hline 3 & Pidana Korupsi & 52 Orang \\
\hline 4 & Pidana Kesusilaan & 26 Orang \\
\hline
\end{tabular}




\begin{tabular}{c|l|c}
\hline \hline No. & \multicolumn{1}{|c|}{ Jenis Kejahatan Khusus } & Jumlah \\
\hline \hline 5 & Pidana Pencurian & 18 Orang \\
\hline 6 & Pidana Penganiayaan & 13 Orang \\
\hline 7 & Pidana Makar RMS & 8 Orang \\
\hline \hline
\end{tabular}

Sumber: Diolah dari Data Lapas Kelas IIA Ambon, Tahun 2018

Tingginya angka tindak pidana korupsi di Maluku menunjukkan menurunnya pengamalan nilai-nilai pancasila dikalangan pejabat daerah termasuk semangat nasionalisme atau kecintaan terhadap bangsa dan negara. Namun demikian para narapidana tindak pidana korupsi bagaimanapun adalah warga negara yang memerlukan pembinaan karakter kebangsaan agar kelak ketika kembali di masyarakat tidak lagi mengulangi perbuatannya dan menjadi warga negara yang baik.

Secara konstitusional negara memiliki tanggung jawab untuk menjaga hak setiap warga negara, sebagaimana berdasarkan Pasal 28C ayat (2) Undang-Undang Dasar Negara Republik Indonesia Tahun 1945 (selanjutnya disebut UUD NRI Tahun 1945), mengatur bahwa "setiap orang berhak untuk memajukan dirinya dalam memperjuangkan haknya secara kolektif untuk membangun masyarakat, bangsa dan negaranya". Artinya, setiap orang termasuk narapidana memiliki hak untuk diberi pembinaan yang berorientasi pada memajukan dirinya dalam membangun masyarakat bangsa dan negara.

Beragamnya jenis kejahatan yang dilakukan narapidana memerlukan strategi pembinaan khususnya dalam pembinaan wawasan kebangsaan dan kenegaraan sesuai dengan klasifikasi jenis kejahatan yang dilakukan. Oleh karena itu, pola pembinaan yang dilakukan pihak Lapas khususnya di Kota Ambon akan memberikan efek positif dalam meningkatkan kesadaran hukum kehidupan berbangsa dan bernegara narapidana tindak pidana korupsi (Agus Hariadi, 2016).

Berdasarkan fakta empiris, tingginya narapidana khusus korupsi di Lapas Kelas IIA Ambon dan sistem norma yang mengatur pembinaan warga binaan, maka kajian ini menarik untuk dilakukan guna melihat efektivitas pembinaan narapidana khusus korupsi, sebab penanaman kesadaran konstitusional dalam berbangsa dan bernegara bagi narapidana khusus korupsi sangat ditentukan oleh strategi dan konsep pembinaan yang mereka dapatkan dari pihak Lapas.

Selanjutnya dapat diketahui bahwa tindak pidana korupsi sebagai salah satu tindak pidana khusus yang biasa disebut dengan extra ordinary crime atau kejahatan luar biasa telah mendapatkan pembinaan yang luar biasa pula, sebab kejahatan yang mereka lakukan yang memiliki perbedaan dengan tindak pidana umum seperti penganiayaan, pencurian, pembunuhan, dan lain-lain. Lebih lanjut, konsep pembinaan dapat merubah kesadaran hukum narapidana sebagai sarana memanusiakan kembali warga binaan agar kelak dapat diterima oleh masyarakat. Selain itu, jiwa nasionalismenya diharapkan dapat tumbuh kembali untuk tidak melakukan tindak pidana korupsi yang sangat merugikan negara dan rakyat, akan tetapi kecintaannya terhadap bangsa ini akan terbangun.

Umumnya kajian sebelumnya lebih banyak melihat dari aspek pemenuhan hakhak semata serta pembinaan dari aspek pembangunan sumber daya manusia yang diberikan belum maksimal. Namun belum banyak yang melihat dari sisi pembinaan narapidana khusus korupsi pada pembangunan kesadaran berbangsa dan bernegara. 
Berdasarkan uraian di atas, maka tujuan penelitian ini adalah untuk mengetahui dan menganalisis efektivitas program pembinaan kesadaran berbangsa dan bernegara terhadap narapidana khusus korupsi di Lapas Kelas IIA Ambon, serta faktor-faktor yang mempengaruhinya.

\section{METODE PENELITIAN}

Penelitian ini merupakan penelitian hukum empiris, yakni penelitian yang memandang hukum dalam konteks sosialnya (Said Sampara \& La Ode Husen, 2016), dan berkaitan dengan program pembinaan kesadaran berbangsa dan bernegara. Penelitian ini dilaksanakan di Kota Ambon, tepatnya di instansi Lapas Kelas IIA Ambon dengan pertimbangan bahwa tempat penelitian ini banyak penghuni narapidana tindak pidana korupsi. Jenis data yang digunakan dalam penelitian ini, adalah sebagai berikut:

1. Data Primer, adalah data yang bersumber dari hasil penelitian lapangan, yakni dari beberapa informan yang telah ditetapkan sebagai sample penelitian.

2. Data Sekunder, adalah data yang bersumber dari penelusuran bahan hukum kepustakaan, berupa dokumen resmi dari instansi terkait, peraturan perundangundangan, jurnal ilmiah hukum, ensiklopedia hukum, maupun dari teks atau terbitan resmi.

Untuk memperoleh data yang dibutuhkan dalam penelitian ini, maka digunakan teknik pengumpulan data, yakni sebagai berikut:

1. Wawancara, yakni dilakukan dengan cara interview secara langsung dengan pihakpihak yang dipandang kompeten memberikan informasi langsung berkenaan dengan masalah yang dikaji dalam penelitian ini;

2. Dokumentasi, dilakukan dengan cara permintaan secara resmi tentang dokumen terkait;

3. Studi Kepustakaan, dilakukan dengan cara menginventarisasi dan menganalisis bahan-bahan hukum kepustakaan yang berkenaan dengan masalah yang dikaji dalam penelitian.

Data yang telah terkumpul, kemudian dibahas dan dianalisis dengan menggunakan model analisis deskriptif, dengan menguraikannya dalam bentuk naratif. Data primer dan data sekunder yang berhasil dihimpun selama berlangsungnya penelitian, kemudian disusun secara sistematik serta dianalisis secara kualitatif menurut validitas dan reliabilitasnya.

\section{HASIL DAN PEMBAHASAN}

\section{A. Substansi Pengaturan Pembinaan Lapas}

Pembinaan narapidana didasarkan pada sistem pemasyarakatan, sebagaimana berdasarkan Pasal 2 Undang-Undang Republik Indonesia Nomor 12 Tahun 1995 tentang Pemasyarakatan (selanjutnya disebut UU No. 12 Tahun 1995), mengatur bahwa:

"Sistem pemasyarakatan diselenggarakan dalam rangka membentuk Warga Binaan Pemasyarakatan agar menjadi manusia seutuhnya, menyadari kesalahan, memperbaiki diri, dan tidak mengulangi tindak pidana sehingga dapat diterima kembali oleh lingkungan masyarakat, dapat aktif berperan dalam pembangunan, dan dapat hidup secara wajar sebagai warga yang baik dan bertanggung jawab." 
Selanjutnya, berdasarkan Pasal 7 ayat (1) dan ayat (2) Peraturan Pemerintah Republik Indonesia Nomor 31 Tahun 1999 tentang Pembinaan dan Pembimbingan Warga Binaan Pemasyarakatan (selanjutnya disebut PP No. 31 Tahun 1999), mengatur bahwa:

(1) Pembinaan Narapidana dilaksanakan melalui beberapa tahap pembinaan.

(2) Tahap pembinaan sebagaimana dimaksud dalam ayat (1) terdiri dari atas 3 (tiga) tahap, yaitu:
a. tahap, awal;
b. tahap lanjutan; dan
c. tahap akhir.

Berdasarkan ruang lingkup pembinaan, BAB VII Pelaksanaan Pembinaan Keputusan Menteri Kehakiman Republik Indonesia Nomor M.02-PK.04.10 Tahun 1990 tentang Pola Pembinaan Narapidana/Tahanan, mengatur bahwa pada dasarnya ruang lingkup pembinaan dapat dibagi ke dalam dua bidang yakni:

1. Pembinaan Kepribadian:

a. Pembinaan kesadaran beragama;

b. Pembinaan kesadaran berbangsa dan bernegara;

c. Pembinaan kemampuan intelektual (kecerdasan);

d. Pembinaan kesadaran hukum; dan

e. Pembinaan mengintegrasikan diri dengan masyarakat.

2. Pembinaan Kemandirian:

a. Keterampilan untuk mendukung usaha-usaha mandiri;

b. Keterampilan untuk mendukung usaha-usaha industri kecil;

c. Keterampilan yang dikembangkan sesuai dengan bakatnya masing-masing; dan

d. Keterampilan untuk mendukung usaha-usaha industri atau kegiatan pertanian (perkebunan) dengan menggunakan teknologi madya atau teknologi tinggi.

Konsep pembinaan narapidana yang dimaksud sebagaimana berdasarkan Pasal 1 PP No. 31 Tahun 1999, menjelaskan bahwa:

"Pembinaan adalah kegiatan untuk meningkatkan kualitas ketaqwaan kepada Tuhan Yang Maha Esa, intelektual, sikap dan perilaku, profesional, kesehatan jasmani dan rohani Narapidana dan Anak Didik Pemasyarakatan."

Secara gramatikal, hukum pembinaan yang dimaksud dalam peraturan tersebut berbagai kegiatan pembinaan yang bertujuan untuk memberikan peningkatan kualitas 5 aspek penting bagi diri narapidana dan dana anak didik pemasyarakatan. Ke lima aspek tersebut adalah:

1. Kualitas Ketaqwaan kepada Tuhan Yang Maha Esa;

2. Kualitas Intelektual;

3. Kualitas Sikap dan Prilaku;

4. Kualitas Profesional Kerja; dan

5. Kualitas Kesehatan Jasmani dan Rohani. 
Adapun berdasarkan Pasal 2 ayat (1) PP No. 31 Tahun 1999, mengatur bahwa "program pembinaan dan pembimbingan meliputi kegiatan pembinaan dan pembimbing kepribadian dan kemandirian".

Kegiatan pembinaan kepribadian bertujuan atau diarahkan pada pembinaan mental dan watak agar bertanggung jawab kepada diri sendiri, keluarga dan masyarakat (Patriandi Nuswantoro, 2017). Adapun kegiatan pembinaan kemandirian bertujuan atau diarahkan pada diarahkan pada pembinaan bakat dan keterampilan agar Warga Binaan Pemasyarakatan dapat kembali berperan sebagai anggota masyarakat yang bebas dan bertanggung jawab (Ludin Lukman Hakim, 2018).

Lebih lanjut, berdasarkan Pasal 2 ayat (1) PP No. 31 Tahun 1999, mengatur bahwa pembinaan dan pembimbingan kepribadian dan kemandirian ... meliputi hal-hal yang berkaitan dengan:

a. ketaqwaan kepada Tuhan Yang Maha Esa;

b. kesadaran berbangsa dan bernegara;

c. intelektual;

d. sikap dan perilaku;

e. kesehatan jasmani dan rohani;

f. kesadaran hukum;

g. reintegrasi sehat dengan masyarakat;

h. keterampilan kerja; dan

i. latihan kerja dan produksi.

Kegiatan Pembinaan warga binaan, sebagaimana berdasarkan Pasal 6 PP No. 31 Tahun 1999, mengatur bahwa:

(1) Kepala Lapas wajib melaksanakan pembinaan Narapidana.

(2) Dalam melaksanakan pembinaan ..., Kepala Lapas wajib mengadakan perencanaan, pelaksanaan dan pengendalian atas kegiatan program pembinaan.

(3) Kegiatan pembinaan ... diarahkan pada kemampuan Narapidana untuk berintegrasi secara sehat dengan masyarakat.

Selanjutnya, berdasarkan Pasal 4 ayat (1) dan ayat (2) PP No. 31 Tahun 1999, mengatur bahwa:

(1) Pelaksanaan pembinaan dan pembimbingan Warga Binaan Pemasyarakatan dilakukan oleh Petugas Pemasyarakatan yang terdiri dari atas:

a. Pembina Pemasyarakatan;

b. Pengaman Pemasyarakatan; dan

c. Pembimbing Kemasyarakatan.

(2) Dalam melaksanakan pembinaan ..., Kepala Lapas menetapkan Petugas Pemasyarakatan yang bertugas sebagai Wali Narapidana dan Anak Didik Pemasyarakatan.

Dari ketentuan di atas, adapun penjelasan Pasal 4 ayat (2) PP No. 31 Tahun 1999, menjelaskan bahwa:

"Penunjukan Wali Narapidana dan Anak Didik Pemasyarakatan dimaksudkan agar setiap warga binaan dalam Lapas dapat dibina dan diamati perkembangannya selama berada dalam binaan yang berkesinambungan." 
Selain pembinaan dan pembimbingan dilakukan secara internal oleh petugas pemasyarakatan yang ada di lapas, berdasarkan Pasal 5 PP No. 31 Tahun 1999, mengatur bahwa:

"Dalam rangka penyelenggarakan pembinaan dan pembimbingan Warga Binaan Pemasyarakatan, Menteri dapat mengadakan kerja sama dengan instansi Pemerintah terkait, badan-badan kemasyarakatan lainnya, atau perorangan yang kegiatannya sesuai dengan penyelenggaraan sistem pemasyarakatan."

Dari ketentuan di atas, adapun penjelasan Pasal 5 PP No. 31 Tahun 1999, menjelaskan bahwa:

"Yang dimaksud dengan 'instansi Pemerintah terkait' adalah instansi pemerintah yang lingkup tugasnya meliputi bidang Agama, Pertanian, Pendidikan dan Kebudayaan, Sosial, Kesehatan, Tenaga Kerja, Perindustrian dan Perdagangan, Pemerintah Daerah, dan lain-lainnya. Yang dimaksud dengan 'Badan-badan Kemasyarakatan lainnya' misalnya, yayasan, koperasi, dan lembaga swadaya masyarakat. Sedangkan yang dimaksud dengan perorangan adalah dokter, psikolog, pengusaha, dan lain-lainnya"

\section{B. Konsep Pembinaan menurut Ahli Hukum}

Konsep pembinaan narapidana dalam kajian literatur telah banyak dibahas oleh berbagai pakar di antaranya, Romli Atmasasmita dengan konsep resosialisasi. Romli Atmasasmita (1982) menjelaskan bahwa:

"Resosialisasi adalah memasyarakatkan kembali para narapidana sehingga menjadi warga masyarakatyang baik dan berguna atau healthy reentry into community."

Velinka Grozdanić \& Ute Karlavaris-Bremer (2007) memberikan penjelasan lebih lanjut bahwa "resosialisasi adalah proses yang mengakomodasi dan memenuhi kebutuhan pelaku tindak pidana akan kebutuhan sosialnya". Adapun kebutuhan sosial dalam perspektif Yong Ohoitimur (1997) yaitu bahwa "kebutuhan sosial pada dasarnya merupakan kebutuhan untuk bersosialisasi dan berinteraksi dengan lingkungan masyarakat".

Yong Ohoitimur (1997) dalam kajiannya menganggap kejahatan sebagai simtom disharmony mental atau ketidakseimbangan personal yang membutuhkan terapi psikiatri, konseling, latihan-latihan spiritual dan sebagainya. Lagi pula karena pemidanaan lebih dipandang sebagai proses terapi atas penyakit yang ada, bukan lagi sebagai penjeraan atau penangkalan dalam konteks deterrence. Teori deterrence sendiri merupakan teori pemidanaan yang bertujuan melakukan pencegahan, yaitu mencegah kerusakan yang besar dari masyarakat akibat dari suatu tindak pidana atau mencegah pelaku mengulangi lagi tindak pidana. Teori rehabilitasi sebagai tujuan pemidanaan dilatarbelakangi pandangan positivistik dalam kriminologi, di mana penyebab kejahatan lebih dikarenakan adanya penyakit kejiwaan atau penyimpanan sosial baik dalam pandangan psikiatri atau psikologi. Di pihak lain kejahatan dalam pandangan rehabilitasi adalah sebagai penyakit sosial disintegratif dalam masyarakat (Abintoro Prakoso, 2019). 
Dari kedua penguraian teori di atas, Eva Achjani Zulfa dalam Abintoro Prakoso (2019) menjelaskan bahwa baik teori resosialisasi dan teori rehabilitasi jelas berbeda, karena dibangun di atas paradigma yang berbeda. Perbedaan itu juga terlihat dari tujuan yang hendak dicapai. Tujuan yang hendak dicapai oleh teori resosialisasi, yaitu untuk memasyarakatkan pelaku, dalam pengertian mendekatkan pelaku dengan masyarakatnya, bukan bertujuan untuk pencegahan dan penjeraan. Namun, apabila teori rehabilitasi direduksi ke dalam teori resosialisasi, maka kedua pendekatannya adalah sama yaitu memandang pelaku sebagai orang yang membutuhkan pertolongan. Hanya saja apabila rehabilitasi menekankan pada bentuk terapi (pertolongan) maka apakah menyosialisasikan pelaku adalah bentuk pengobatan?. Mengutip pernyataan Kepala Jawatan Kepenjaraan pada tahun 1962, Soedarman Gondosoebroto dalam Abintoro Prakoso (2019), bahwa "konsep pemasyarakatan pada dasarnya adalah sama dengan teori resosialisasi yang dikembangkan di banyak negara dewasa ini". Konsep pemasyarakatan yang dikenal di Indonesia pada dasarnya merupakan konsep yang ditawarkan oleh Dr. Saharjo pada tanggal 5 juli 1963 yang ditujukan untuk menggantikan konsep penjara peninggalan Pemerintah Kolonial Hindia Belanda, bahwa tujuan pemidanaan adalah pemasyarakatan (Abintoro Prakoso, 2019).

Tujuan utama dari Lapas sebagaimana menurut Djisman Samosir (2012), yaitu bahwa:

"Lapas harus melakukan pembinaan bagi warga binaan pemasyarakatan berdasarkan sistem kelembagaan dan cara pembinaan sebagai bagian akhir dari sistem pemidanaan dalam sistem peradilan pidana. Lapas harus mempersiapkan berbagai program pembinaan bagi para narapidana sesuai dengan tingkat pendidikan jenis kelamin, agama, dan tindak pidana yang dilakukan narapidana tersebut. Program pembinaan bagi narapidana disesuaikan pula dengan lama hukuman yang akan dijalani para narapidana dan anak didik, agar mencapai sasaran yang ditetapkan, yaitu agar mereka menjadi warga yang baik di kemudian hari."

Program-program pembinaan narapidana dan anak didik yang ditetapkan pemerintah sesuai undang-undang bertujuan agar para narapidana dan anak didik kembali ke masyarakat dan dapat berpartisipasi dalam membangun bangsa (Abintoro Prakoso, 2019).

Namun kehadiran mereka di masyarakat tidak semudah yang kita bayangkan. Hal ini dikarenakan oleh masyarakat swear yang dimana pada saat narapidana dan anak didik dipenjara terjadi prisonisasi yaitu pengambilalihan atau peniruan tentang tata cara, adat istiadat dan budaya para narapidana dan anak didik pada saat melakukan tindak pidana, sebagaimana diungkapkan oleh Donald Clemmer (1958) bahwa "prisonization as the taking on in greater or lesser degree, of the folkways, mores, customs and general cultur of the penitentiary". Lebih lanjut, Djisman Samosir (2012), mengungkapkan bahwa:

"Lapas sebagai instansi terakhir dalam pembinaan narapidana harus memperhatikan secara sungguh-sungguh hak dan kepentingan narapidana (warga binaan yang bersangkutan). Harus diakui bahwa peran serta Lapas dalam membina warga binaan sangat strategis dan dominan, terutama dalam memulihkan kondisi warga binaan pada 
kondisi sebelum melakukan tindakan pidana, dan melakukan pembinaan di bidang kerohanian dan keterampilan seperti pertukangan, menjahit dan sebagainya."

\section{Kegiatan Pembinaan Narapidana Khusus Korupsi di Lapas Kelas IIA Ambon} Dari data yang diperoleh, ditemukan kegiatan pembinaan yang dilakukan Lapas Kelas IIA Ambon yang dapat dilihat pada tabel di bawah ini.

Tabel 2. Program dan Sarana Kegiatan Pembinaan Warga Binaan Lapas Kelas IIA Ambon

\begin{tabular}{|c|c|c|c|}
\hline No. & Program Pembinaan & Sarana/Kegiatan & $\overline{\text { Waktu }}$ \\
\hline \multirow[t]{4}{*}{ A. } & \multirow[t]{4}{*}{ Pembinaan Kemandirian } & Bengkel Besi, Kayu, Sofa & Tiap Hari \\
\hline & & Pertukangan & Tiap Hari \\
\hline & & Pertanian & Tentatif \\
\hline & & Sosialisasi, Pelatihan & Tentatif \\
\hline \multirow[t]{5}{*}{ B. } & \multirow[t]{5}{*}{ Pembinaan Kepribadian } & Masjid & Jum'at \\
\hline & & Gereja & Senin, Rabu, Sabtu \\
\hline & & Ceramah & Kamis, Minggu \\
\hline & & Upacara Bendera & Senin \\
\hline & & Perpustakaan & Setiap Hari \\
\hline \multirow[t]{3}{*}{ C. } & \multirow[t]{3}{*}{ Pembinaan Jasmani } & Lapangan Bola & Setiap Hari \\
\hline & & Badminton & Setiap Saat \\
\hline & & Senam & Setiap Minggu \\
\hline \multirow[t]{2}{*}{ D. } & \multirow[t]{2}{*}{ Pembinaan Sikap dan Perilaku } & Apel di Blok-Blok Hunian & \\
\hline & & Penggeledahan di Kamar-Kamar & Berkala dan Insidentil \\
\hline
\end{tabular}

Sumber: Diolah dari Data Lapas Kelas IIA Ambon, Tahun 2019

Dari tabel di atas, kegiatan pembinaan yang dapat kita kaitkan dengan kesadaran berbangsa dan bernegara adalah upacara bendera yang dilakukan setiap hari senin pada bulan berjalan. Kegiatan ini melibatkan seluruh warga binaan tidak terkecuali narapidana khusus korupsi. Narapidana atau warga binaan juga bergantian menjadi petugas upacara, yang terdiri dari pengibar bendera, pembaca teks pembukaan UUD NRI Tahun 1945, komandan upacara, pembacaan doa, dan lain sebagainya.
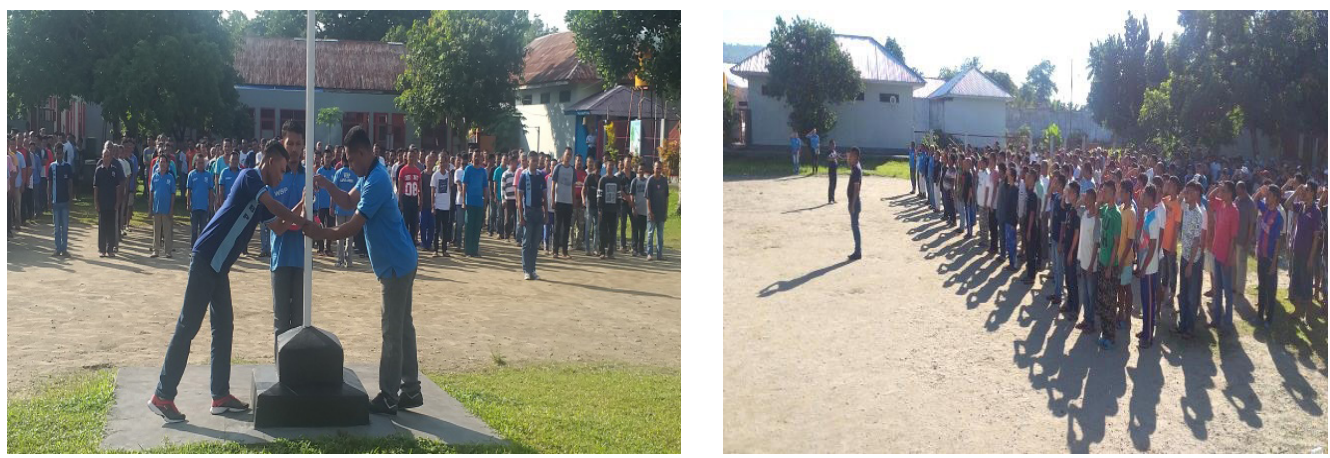

Berdasarkan fasilitas atau sarana prasarana yang dimiliki untuk melakukan kegiatan pembinaan kemandirian dan kepribadian narapidana khusus korupsi belum memadai sebab pilihan yang tersedia sangat terbatas. 
Dari hasil wawancara dengan beberapa warga binaan tindak pidana korupsi mereka berpandangan bahwa pembinaan secara umum sudah jalan dengan baik namun ke depan perlu pembinaan khusus bagi narapidana khusus korupsi, seperti yang dikemukakan warga binaan berinisial L, bahwa: ${ }^{1}$

"Pembinaan ini kalau secara umum sudah jalan baik yang pidana umum, seperti ibadah, upacara, ada pelatihan instansi terkait. selain itu pembinaan khusus ada dari pertanian, depnaker yang ikut itu individu, sedangkan untuk tipikor mungkin pertimbangannya karena agak khusus mungkin pelatihan, yang pembinaan khusus mungkin belum tapi yang umum sudah ada. Sepertinya perlu pembinaan khusus untuk narapidana tipikor, artinya dicari model-model lain yang cocok, karena bicara tipikor, di sinikan pada umumnya mantan-mantan pejabat sehingga tingkat pemahamannya itu karena kalau disuruh diikutkan untuk pembinaan yang narapidana umum, mungkin kurang pas."

Berdasarkan hasil wawancara dan penelusuran dokumen kegiatan warga binaan di atas, maka nampak bahwa kegiatan pembinaan yang mendukung lahirnya kesadaran hukum dalam kehidupan berbangsa dan bernegara relatif belum memadai.

Padahal jika dikaitkan dengan teori dan studi yang berkaitan dengan kesadaran hukum, maka faktor utama yang membentuk pola kesadaran hukum masyarakat ialah ada tidaknya pengetahuan hukum dan prilaku hukum yang nampak dalam tindakan atau keputusan. Sebagaimana yang dikemukakan oleh Achmad Ali (2009), bahwa:

"Studi kesadaran hukum mengkaji tentang bagaimana pengetahuan seseorang tentang hukum, dapat ditransfer ke dalam tindakan dan keputusan yang diambil setiap orang. Lebih dari sekadar sikap hukum dan opini seseorang, maka sebaiknya kajian tentang hukum juga menyelidiki seberapa jauh konsep hukum yang diketahui seseorang, ikut memengaruhi tujuan, pilihan, dan permasalahan yang dialami setiap orang. Dengan cara ini, para pakar kajian 'kesadaran hukum', juga mengkaji faktor-faktor yang menyebabkan seseorang memilih bersikap, apalagi berada di hadapan hukum (before the law), atau bertindak sesuai hukum (within the law) atau malah melanggar hukum (against the law)."

Dari pemikiran tersebut jika dikaitkan dengan program pembinaan dan hasil wawancara dengan warga binaan narapidana khusus korupsi di Lapas Kelas IIA Ambon, dimana belum menunjukkan suatu upaya penanaman pengetahuan hukum yang berkaitan dengan pembangunan mental dan kesadaran berbangsa dan bernegara. Dalam arti penanaman pengetahuan hukum kehidupan berbangsa dan bernegara diwujudkan melalui kegiatan literasi, pelatihan atau seminar dan lain-lain. Sehingga melalui kegiatan tersebut pengetahuan warga binaan bisa terbangun.

Di samping aspek pengetahuan, faktor lain yang bisa diukur adalah sejauh mana tindakan atau prilaku hukum yang ditunjukkan warga binaan dalam konteks kesadaran berbangsa dan bernegara. Dari sejumlah kegiatan pembinaan yang dilakukan di Lapas Kelas IIA Ambon menunjukkan tindakan warga binaan tindak 2019.

${ }^{1}$ Wawancara dengan Narapidana Khusus Korupsi, Lapas Kelas IIA Ambon, pada Tanggal 15 Oktober 
pidana korupsi yang dapat diukur hanya melalui keikutsertaan dalam kegiatan upacara bendera.

Berdasarkan hasil wawancara diperoleh gambaran bahwa minat keikutsertaan warga binaan narapidana khusus korupsi bisa dikatakan relatif baik sebab secara rutin mereka lakukan setiap hari senin sesuai dengan waktu yang telah ditentukan, meskipun keterlibatan dalam mengambil peran dalam kegiatan tersebut masih kurang karena ada kecenderungan peran-peran petugas upacara lebih diserahkan kepada warga binaan yang umurnya lebih muda, karena warga binaan tindak pidana korupsi umumnya memiliki usia yang relatif lebih tua.

Selanjutnya, Achmad Ali (2009) juga mengaitkan beberapa pemikirannya tentang faktor yang menjadi fokus pilihan dalam kajian tentang kesadaran hukum, bahwa:

"Studi kesadaran hukum juga menekankan tentang sumber otoritas, dimana sangat erat kaitannya dengan lokasi dari suatu tindakan hukum terjadi; dan studi tentang kesadaran hukum memerlukan observasi, yang tidak hanya pada apa yang individu katakan kepada peneliti dan juga tidak sekadar terhadap apa yang mereka pikirkan tentang permasalahan sosial dan peranan hukum dalam memperbaiki kehidupan mereka, tetapi juga apa yang mereka lakukan."

Pemikiran di atas menekankan pengaruh hukum sebagai sumber otoritas sangat erat kaitannya dengan lokasi dimana suatu tindakan hukum terjadi, artinya peraturan yang dibuat pihak Lapas Kelas IIA Ambon akan mempengaruhi tindakan warga binaan dalam kaitan dengan konsep pembinaan warga binaan dari tindak pidana korupsi yang secara faktual masih disamakan dengan warga binaan dari tindak pidana umum, sehingga menyebabkan tidak efektifnya pembinaan kesadaran berbangsa dan bernegara, padahal idealnya ada peraturan yang lebih khusus menyangkut pembinaan narapidana khusus korupsi sesuai bakat dan kebutuhan dan latar belakang masing-masing.

Di samping itu, observasi yang dilakukan terhadap keseharian narapidana khusus korupsi telah menunjukkan prilaku atau tindakan di Lapas lebih bersifat monoton pada rutinitas keseharian sesuai jadwal yang ada, umumnya dihabiskan pada kegiatan santai, istirahat atau sekedar jalan-jalan seperti pengakuan dari warga binaan berinisial SI, bahwa: ${ }^{2}$

"Pembinaan kita kan untuk tipikor, pembinaan hanya ibadah saja. Kita tidak di bengkel, BLK tidak ada yang cocok bagi saya selama ini, hanya beribadah, kita ibadah senin, rabu sabtu, minggu. Selain itu, ya jalanjalan, olah raga, sesekali masuk di perpustakaan."

\section{Faktor-Faktor Berpengaruh Efektifitas Pembinaan Narapidana Khusus Korupsi}

Berdasarkan hasil observasi, wawancara dan penelusuran dokumen hukum yang berkaitan dengan konsep pembinaan narapidana, maka ditemukan beberapa kelemahan yang akan mempengaruhi kualitas pembinaan narapidana khusus korupsi.

${ }^{2}$ Wawancara dengan Narapidana Khusus Korupsi, Lapas Kelas IIA Ambon, pada Tanggal 15 Oktober 2019. 


\section{Ketersediaan Sistem Regulasi yang Baik}

Lapas Kelas IIA Ambon merupakan institusi pemerintah vertikal yang berada di bawah Kementerian Hukum dan HAM, sehingga mekanisme dan sistem kerjanya semuanya diatur dan ditentukan oleh pemerintah pusat dalam hal ini Kementerian Hukum dan HAM di Jakarta.

Terdapat kendala kepala Lapas dalam melakukan kerjasama dengan instansi terkait, individu atau lembaga-lembaga sosial sebab yang bisa melakukan kerjasama hal tersebut tidak bisa dilakukan oleh pihak Lapas tetapi kerjasamanya harus dilakukan oleh Menteri. Inilah yang menyebabkan keterbatasan pembinaan untuk melibatkan pihak luar Lapas karena pihak Lapas tidak diberi kewenangan untuk itu. Sehingga ada kesan Lapas di daerah kurang terurus oleh pemerintah pusat. Hal ini secara tersirat dapat dinilai berdasarkan penjelasan dari pegawai Lapas Kelas IIA Ambon berinisial A, bahwa: ${ }^{3}$

"Memang ada keterbatasan dalam hal fasilitas kerjasama selama ini. Kami dari pihak Lapas tidak pernah dimintai kerja sama dengan instansi lain seperti Pemerintah Kota Ambon, padahal harus dicatat bahwa mayoritas warga binaan merupakan masyarakat kota Ambon."

Dari ungkapan di atas, berdasarkan pandangan Eva Achjani Zulfa dalam Abintoro Prakoso (2019), bahwa:

"Diperlukan hasratyang luarbiasa untukdapatmelakukan perubahan terhadap kondisi pemasyarakatan di masa depan. Sekarang kondisi yang terjadi di Lapas merupakan dampak dari kebijakan pemerintah yang cenderung meninggalkan lembaga ini. Sebagai lembaga yang menjadi fase terakhir dari proses peradilan pidana."

Lebih lanjut, Eva Achjani Zulfa dalam Abintoro Prakoso (2019) berpendapat bahwa:

"Kondisi yang terlupakan (ditinggalkan) inilah yang menjadikan kebijakan regulasi Lapas tidak menyeluruh dan tidak memadai. Beberapa aturan sebagaimana disampaikan terdahulu nampaknya harus ditinjau kembali. Apalagi dikaitkan dengan adanya tuntutan dari standar minimum rules for treatment of prisoners yang mensyaratkan bahwa kebutuhan narapidana selayaknya disediakan oleh pemerintah dalam rangka menunjang proses pembinaan yang berlangsung. Karena diperlukan kebijakan yang dapat menunjang kondisi tersebut yang meliputi management system pembinaan narapidana, masalah pendanaan bagi ketersediaan sarana dan prasarana serta kesejahteraan petugas."

Pemikiran ini sangat relevan jika dikaitkan dengan fungsi hukum yang salah satunya adalah sebagai instrumen sarana untuk melakukan perubahan sosial. Artinya, sistem regulasi yang ada seharusnya mampu menciptakan suatu perubahan atau perekayasaan sosial dari suatu keadaan atau situasi masyarakat atau individu tertentu menjadi kondisi atau situasi masyarakat dan individu yang diharapkan dalam konteks tujuan pemasyarakatan, yaitu bagaimana mencegah narapidana ketika kembali ke masyarakat tidak mengulangi tindak pidana yang pernah dilakukan, dan menjadi anggota masyarakat yang baik.

${ }^{3}$ Wawancara dengan Pegawai Lapas Kelas IIA Ambon, pada Tanggal 5 September 2019. 


\section{Ketersediaan Sumber daya Manusia yang Berkualitas}

Selain adanya sistem regulasi yang baik, strategi lain yang juga perlu mendapat perhatian dalam pembinaan adalah ketersediaan pembina yang berkualitas. Narapidana khusus korupsi merupakan narapidana yang memiliki latarbelakang yang berbeda dengan narapidana lain baik dari sisi pendidikan, pekerjaan maupun latar belakang melakukan tindak pidana. Berdasarkan data yang dihimpun, narapidana khusus korupsi di Lapas IIA Ambon umumnya aparatur sipil negara (ASN) dan telah berpendidikan tinggi. Olehnya itu, pembinaan mental dan spiritual akan sangat menentukan kualitas lebih baik jika para pembina memiliki kualifikasi yang lebih baik dari sisi pendidikan maupun pengalaman.

Pembinaan mental narapidana khusus korupsi sangat penting sebab yang paling utama diharapkan dari hasil pembinaan adalah narapidana khusus korupsi menyadari kesalahan yang diperbuat bahwa perbuatan korupsi merupakan perbuatan yang tidak baik selain merugikan diri sendiri karena membiasakan sifat koruptif (menyeleweng), tetapi juga merugikan keuangan negara yang sangat membutuhkan dana untuk pembangunan dan termasuk menggaji aparaturnya. Pada akhirnya, korupsi juga merugikan masyarakat dan rakyat, sebab seharusnya dana negara yang sejatinya digunakan untuk membiayai program-program pemerintah dalam pelayanan publik, namun karena prilaku korupsi akibatnya program-program atau proyek-proyek pembangunan tidak maksimal. Namun, berdasarkan ungkapan dari pegawai SDM Lapas Kelas IIA Ambon berinisial M, bahwa: ${ }^{4}$

"Kita tidak ada psikolog di lapas, kalau menurut saya penting mungkin di UPT lain ada, pejabat, petugas lapas harus banyak fungsi, dia juga harus bertugas sebagai psikolog jadi luar biasa dan Pos pelayanan masyarakat khusus masalah HAM dari divisi pelayanan hukum."

Secara struktural organisasi lembaga kemasyarakatan Ambon, pembinaan narapidana dilakukan oleh Wali Pemasyarakatan berdasarkan ketentuan perundang-undangan yang berlaku, bahwa kegiatan Pembinaan warga binaan pemasyarakatan merupakan kewajiban yang dilaksanakan oleh Kepala Lapas. Selanjutnya, Kepala Lapas mengangkat petugas pemasyarakatan untuk menjadi Wali narapidana untuk melaksanakan pembinaan dan pembimbingan tersebut. Penunjukkan Wali Narapidana dan Anak Didik Pemasyarakatan dimaksudkan agar setiap warga binaan dalam Lapas dapat dibina dan diamati perkembangannya selama berada dalam binaan yang berkesinambungan.

Kepala Lapas Kelas IIA Ambon telah mengangkat Wali Narapidana yang masing-masing memiliki bagian dan tanggung jawab masing-masing mereka itu adalah:

1) J. Pattikawa, S.Sos. (Bagian Pentahapan);

2) E. Pattikawa (Bagian Kerohanian Kristen dan Kesadaran Berbangsa dan Bernegara);

3) J. J. Latumeten (bagian Bahan Makanan WBP);

4) Firman Satrianti (Petugas Sistem Pemasyarakatan Kerohanian Islam dan Perkembangan);

${ }^{4}$ Wawancara dengan Pegawai SDM Lapas Kelas IIA Ambon, pada Tanggal 5 September 2019. 
5) A. Samallo, Amd.Kep. (Bagian Perawat/Petugas Kesehatan);

6) J. Litaoy, S.Kep. (Bagian Perawat/Petugas Kesehatan);

7) Hery Prianto, S.Kep. (Bagian Perawat/Petugas Kesehatan).

Kualitas dan kompetensi keilmuan para petugas kemasyarakatan dan wali narapidana sangat berpengaruh pada kualitas pembinaan narapidana, sehingga latar belakang keilmuan para wali narapidana diharapkan sesuai target kualitas pembinaan yang diharapkan oleh peraturan perundang-undangan yakni kualitas ketaqwaan kepada Tuhan Yang Maha Esa, kualitas intelektual, kualitas sikap dan prilaku, kualitas profesional kerja, dan kualitas kesehatan jasmani dan rohani.

Dalam konteks membangun kualitas ketaqwaan dan kesehatan rohani maka petugas SDM dari disiplin ilmu agama sangat diperlukan, di Lapas Kelas IIA Ambon dari identifikasi latar belakang keilmuan belum memadai SDM dari sarjana agama, demikian pula untuk mewujudkan kualitas sikap dan prilaku maka keberadaan SDM dari latar belakang Psikologi perkembangan juga dibutuhkan untuk memberikan konseling dan pembimbingan dalam melihat perkembangan sikap dan perilaku narapidana. Sementara SDM di Lapas Ambon belum memiliki SDM yang memadai dari disiplin ilmu psikologi.

Jika dikaitkan dengan teori implementasi kebijakan, Larry N. Gerston (1992) mengategorikan 4 (empat) faktor yang mempengaruhi berhasil tidaknya implementasi kebijakan, yaitu:

1) translation ability, kemampuan staf pelaksana untuk menerjemahkan apa yang sudah diputuskan oleh pengambil kebijakan untuk dilaksanakan;

2) resources (sumber daya), khususnya yang berkaitan sumber daya manusia, peralatan/sarana dan prasarana;

3) limited number of players, yaitu jumlah pelaksanaan kebijakan yang tidak terlalu banyak, agar tidak menimbulkan kebingungan, benturan antar kewenangan dan juga kompetisi yang tidak sehat;

4) accountability, yaitu adanya pertanggungjawaban dari pelaksana kebijakan terhadap apa yang telah dihasilkan.

Maka faktor translation ability dan resources atau ketersediaan SDM sangat berpengaruh terhadap implementasi kebijakan yang terkait dengan pembinaan kesadaran berbangsa dan bernegara sebagai bagian yang menjadi capaian kualitas pembinaan. Sehingga keterbatasan SDM dan sarana prasarana yang dimiliki Lapas Kelas IIA Ambon sangat mempengaruhi implementasi UU No. 12 Tahun 1995 itu sendiri.

\section{Ketersediaan Sumber Daya Finansial yang Memadai}

Hal-hal lain yang harus mendapat dalam pembinaan narapidana khusus korupsi adalah tersedianya anggaran pembinaan yang memadai sebab kualitas pembinaan narapidana tidak bisa dilepaskan dari kuantitas anggaran sebab semakin besar anggaran yang ada akan semakin besar pula kegiatan pembinaan yang bisa dilakukan. Dari hasil penelusuran dokumen anggaran di Lapas Kelas IIA Ambon ditemukan realisasi pelayanan pemasyarakatan tahun 2019 sebagaimana dapat di lihat dalam tabel berikut ini. 
Tabel 3. Indikator dan Realisasi Anggaran Pelayanan Pemasyarakatan Lapas Kelas IIA Ambon Tahun 2019

\begin{tabular}{|c|c|c|c|c|c|c|}
\hline No. & Program & Kegiatan & Target & $\begin{array}{l}\text { Jumlah } \\
\text { Narapidana }\end{array}$ & $\begin{array}{c}\text { Realisasi } \\
\text { Kinerja }\end{array}$ & $\begin{array}{l}\text { Realisasi } \\
\text { Anggaran }\end{array}$ \\
\hline \multirow[t]{8}{*}{1} & \multirow{4}{*}{\begin{tabular}{|l} 
Layanan \\
Pembinaan \\
Narapidana
\end{tabular}} & \multirow{4}{*}{$\begin{array}{l}\text { Pembinaan } \\
\text { Kepribadian dan } \\
\text { Layanan Integritas } \\
\text { Narapidana }\end{array}$} & TW1 & 124 & 79 & 6.940 .000 \\
\hline & & & TW2 & 248 & 95 & 16.690 .000 \\
\hline & & & TW3 & 372 & & 16.690 .000 \\
\hline & & & TW4 & 502 & & 16.690 .000 \\
\hline & & \multirow{4}{*}{$\begin{array}{l}\text { Pembinaan } \\
\text { Kemandirian } \\
\text { Narapidana }\end{array}$} & TW1 & 124 & & \\
\hline & & & TW2 & 248 & 46 & 17.700 .000 \\
\hline & & & TW3 & 372 & & 17.700 .000 \\
\hline & & & TW4 & 502 & & 17.700 .000 \\
\hline \multirow[t]{4}{*}{2} & \multirow{4}{*}{$\begin{array}{l}\text { Layanan } \\
\text { Perawatan } \\
\text { Narapidana/ } \\
\text { tahanan }\end{array}$} & \multirow{4}{*}{$\begin{array}{l}\text { Kebutuhan Dasar } \\
\text { Kesehatan Lingkungan } \\
\text { dan Layanan } \\
\text { Rehabilitasi }\end{array}$} & TW1 & 124 & & 654.991 .610 \\
\hline & & & TW2 & 248 & 60 & 1.562 .926 .359 \\
\hline & & & TW3 & 372 & 71 & 1.562 .926 .359 \\
\hline & & & TW4 & 502 & & 1.562 .926 .359 \\
\hline
\end{tabular}

Sumber: Diolah dari Data Lapas Kelas IIA Ambon, Tahun 2019

Berdasarkan tabel di atas, terlihat realisasi anggaran layanan pembinaan narapidana untuk kegiatan pembinaan kepribadian setiap triwulan dianggarkan rata-rata sebesar Rp. 16.690.000,00, sedangkan anggaran untuk kegiatan pembinaan kemandirian sebesar Rp. 17.700.000,00.

\section{KESIMPULAN}

Berdasarkan uraian hasil dan pembahasan, maka dapat disimpulkan bahwa program pembinaan kesadaran berbangsa dan bernegara terhadap narapidana khusus korupsi di Lembaga Pemasyarakatan Kelas IIA Ambon belum berjalan secara efektif. Hal ini disebabkan masih adanya sejumlah kendala, yakni adanya keterbatasan program pembinaan dari pemerintah pusat, kewenangan yang dimiliki, kurangnya anggaran, minimnya sarana dan prasarana serta kurangnya SDM dalam menunjang kepribadian berbangsa bernegara, sebab kegiatan pembinaannya masih sebatas kegiatan upacara bendera. Adapun Faktor yang mempengaruhi efektivitas pembinaan yakni ketersediaan regulasi yang kurang mendukung, ketersediaan sumber daya manusia yang belum memadai dan ketersediaan anggara pembinaan yang masih kecil. Dengan dasar kesimpulan tersebut, disarankan agar dilakukan penambahan tenaga Sumber Daya Manusia yang memiliki kapasitas dan kompetensi untuk memberikan bekal yang cukup bagi narapidana khusus korupsi. Lebih lanjut, diperlukan perubahan regulasi di bidang lembaga kemasyarakatan dengan memberikan kewenangan kepada pihak Lembaga Pemasyarakatan untuk dapat melakukan berbagai Nota Kesepahaman dengan berbagai instansi guna mengoptimalkan kerjasama kegiatan pembinaan di bidang kesadaran berbangsa dan bernegara. 


\section{REFERENSI}

Abintoro Prakoso. (2019). Hukum Penitensier. Yogyakarta: Aswaja Pressindo.

Achmad Ali. (2009). Menguak Teori Hukum (Legal Theory) dan Teori Peradilan (Judicialprudence): Termasuk Interpretasi Undang-Undang (Legisprudence). Jakarta: Kencana Prenada Media Group.

Agus Hariadi. (2016). Suatu Dilema dalam Pembinaan Narapidana Koruptor di Lembaga Pemasyarakatan. Jurnal Legislasi Indonesia, Kementerian Hukum dan Hak Asasi Manusia RI, 13(3), hlm. 297-308.

Ainna Amalia \& Ricardo Freedom Nanuru. (2018). Toleransi Beragama Masyarakat Bali, Papua, Maluku. Jurnal Darussalam: Jurnal Pendidikan, Komunikasi dan Pemikiran Hukum Islam, Institut Agama Islam Darussalam Blokagung Banyuwangi, 10(1), hlm. 150-161. doi: https://doi.org/10.30739/darussalam.v10i1.276

Chandro Panjaitan \& Firman Wijaya. (2018). Penyebab Terjadinya Tindakan Main Hakim Sendiri atau Eigenrichting yang Mengakibatkan Kematian (Contoh Kasus Pembakaran Pelaku Pencurian Motor dengan Kekerasan di Pondok Aren Tangerang). Jurnal Hukum Adigama, Universitas Tarumanagara, 1(1), hlm. 1-25. doi: http://dx.doi.org/10.24912/adigama.v1i1.2168

Choirul Arifin. (2018, 4 Oktober). OTT di Kantor Pajak Pratama Ambon, KPK Tetapkan Tiga Tersangka. Dalam Tribunnews.com. Diakses dari https://www.tribunnews. com/nasional/2018/10/04/ott-di-kantor-pajak-pratama-ambon-kpk-tetapkantiga-tersangka, pada tanggal 22 September 2019.

Dimas Prasetyo. (2017). Posisi Polri dalam Penanganan Demo Anarkis (Studi Kasus Tawuran Mahasiswa UMI Makassar). Jurnal Ilmu Kepolisian, Sekolah Tinggi Ilmu Kepolisian, 11(1), hlm. 73-79.

Djisman Samosir. (2012). Sekelumit tentang Penologi \& Pemasyarakatan. Bandung: Nuansa Aulia.

Donald Clemmer. (1958). The Prison Community. New York: Holt, Rinehart and Winston.

Haris Fadhil. (2018, 3 September). Miris! 41 dari 45 Anggota DPRD Malang Jadi Tersangka Korupsi. Dalam Detik.com. Diakses dari https://news.detik.com/ berita/d-4195618/miris-41-dari-45-anggota-dprd-malang-jadi-tersangkakorupsi, pada tanggal 22 September 2019.

Ibnu Hariyanto. (2019, 27 September). Eks Menpora Imam Nahrawi Tersangka Suap Penuhi Panggilan KPK. Dalam Detik.com. Diakses dari https://news.detik. com/berita/d-4724022/eks-menpora-imam-nahrawi-tersangka-suap-penuhipanggilan-kpk, pada tanggal 22 Oktober 2019.

Ibrahim Ahmad. (2018). Rencana dan Strategi Peningkatan Kesadaran Hukum Masyarakat. Gorontalo Law Review, Universitas Gorontalo, 1(1), hlm. 15-24.

Ilham Rian Pratama. (2019, 29 Juli). Bupati Kudus Dua Kali Tersandung Kasus Korupsi dan Suap, Pentingnya Pencabutan Hak Politik. Dalam Tribunnews.com. Diakses dari https://www.tribunnews.com/nasional/2019/07/29/bupati-kudusdua-kali-tersandung-kasus-korupsi-dan-suap-pentingnya-pencabutan-hakpolitik? page=3, pada tanggal 25 Oktober 2019 . 
Keputusan Menteri Kehakiman Republik Indonesia Nomor M.02-PK.04.10 Tahun 1990 tentang Pola Pembinaan Narapidana/Tahanan.

La Ode Husen. (2015). Menegakkan Etika dan Kehormatan Penyelenggara Negara dapat Mencegah Terjadinya Korupsi. Jurnal Etika dan Pemilu, Dewan Kehormatan Penyelenggara Pemilu, 1(1), hlm. 17-23.

Larry N. Gerston. (1992). Public Policymaking in a Democratic Society: A Guide to Civic Engagement. New York: M.E. Sharpe, Inc.

Ludin Lukman Hakim. (2018). "Pelaksanaan Pembinaan Warga Binaan di Lembaga Pemasyarakatan Klas IIA Kabupaten Bojonegoro: Studi Kasus di Lembaga Kemasyarakatan Klas IIA Kabupaten Bojonegoro". Disertasi. Universitas Bojonegoro, Bojonegoro.

M. Rosseno Aji. (2019, 23 April). Idrus Marham Divonis Tiga Tahun Penjara di Kasus PLTU Riau-1. Dalam Tempo.co. Diakses dari https://nasional.tempo.co/ read/1198396/idrus-marham-divonis-tiga-tahun-penjara-di-kasus-pltu-riau-1, pada tanggal 25 September 2019.

Miftah Salis. (2019, 16 Maret). Fakta Penangkapan Romahurmuziy Dugaan Suap Pengisian Jabatan Kemenag, KPK Amankan Uang Ratusan Juta. Dalam Tribunnews. com. Diakses dari https://www.tribunnews.com/section/2019/03/16/faktapenangkapan-romahurmuziy-dugaan-suap-pengisian-jabatan-kemenag-kpkamankan-uang-ratusan-juta?page=all, pada tanggal 22 Oktober 2019.

Patriandi Nuswantoro. (2017). Pembinaan Mental Narapidana pada Lembaga Pemasyarakatan Kelas II B Kabupaten Aceh Tengah. Biram Samtani Sains, Universitas Gajah Putih, 1(3), hlm. 1-16.

Peraturan Pemerintah Republik Indonesia Nomor 31 Tahun 1999 tentang Pembinaan dan Pembimbingan Warga Binaan Pemasyarakatan. (Lembaran Negara Republik Indonesia Tahun 1999 Nomor 68. Tambahan Lembaran Negara Republik Indonesia Nomor 3845).

Romli Atmasasmita. (1982). Strategi Pembinaan Pelanggar Hukum dalam Konteks Penegakan Hukum di Indonesia. Bandung: PT. Alumni.

Said Sampara \& La Ode Husen. (2016). Metode Penelitian Hukum. Makassar: Kretakupa Print.

Salman Al Farisi. (2018). "Tindak Pidana Persekusi terhadap Pelaku Penghina Ulama”. Skripsi. Fakultas Syariah dan Hukum, Universitas Islam Negeri Syarif Hidayatullah Jakarta, Jakarta.

Siti Merida Hutagalung. (2011). Penegakan Hukum di Indonesia: Apakah Indonesia Negara Hukum? Sociae Polites: Majalah Ilmiah Sosial-Politik, Universitas Kristen Indonesia, Edisi Khusus November, hlm. 109-126. doi: https://doi.org/10.33541/ sp.v1i1.465

Undang-Undang Dasar Negara Republik Indonesia Tahun 1945.

Undang-Undang Republik Indonesia Nomor 12 Tahun 1995 tentang Pemasyarakatan. (Lembaran Negara Republik Indonesia Tahun 1995 Nomor 77. Tambahan Lembaran Negara Republik Indonesia Nomor 3614). 
Velinka Grozdanić \& Ute Karlavaris-Bremer. (2007). “A Written Word From Women's Prison in the Function of Resocialization". Laporan Hasil Penelitian. University of Rijeka, Rijeka.

Yong Ohoitimur. (1997). Teori Etika tentang Hukuman Legal. Jakarta: PT. Gramedia Pustaka Utama.

Nasaruddin Umar \& Fahri Bachmid. (2020). Efektivitas Program Pembinaan I Kesadaran Berbangsa dan Bernegara terhadap Narapidana Khusus Korupsi di I Lembaga Pemasyarakatan Kelas IIA Ambon. Sovereign: Jurnal Ilmiah Hukum, CV. Social ' I Politic Genius (SIGn), 2(2), hlm. 52-69. doi: https://doi.org/10.37276/sjih.v2i2.38 ا ' ᄂ - - - - - - - - - - - - - - - - - - - - - - - - - - 4 